\title{
Constraints on the ore-forming age of the Yuanjiang marble-hosted ruby deposit, Southwest China \\ YANG TIAN JIAN
}

South China Institute of Environmental Science, the Ministry of Environmental Protection of PRC

Presenting Author: yangtj@mail2.sysu.edu.cn

Constraints on the ore-forming age of the Yuanjiang marblehosted ruby deposit, Southwest China

Tianjian Yang ${ }^{1,2}$, Xiaoming Sun ${ }^{2 *}$, Guiyong Shi ${ }^{2}$

${ }^{1}$ South China Institute of Environmental Science, the Ministry of Environmental Protection of PRC, Guangzhou 510655, China (*correspondence: eessxm@mail.sysu.edu.cn)

${ }^{2}$ Guangdong Provincial Key Laboratory of Marine Resources and Coastal Engineering, Guangzhou 510275, China

The high price and exceptional formation geological conditions empower ruby with both economic and academic interests. As one of the marble-hosted ruby deposits in Central and Southeast Asia, the Yuanjiang marble-hosted ruby deposit is the only economic ruby deposit in China up to now.

Genesis of the Yuanjiang ruby deposit and its genetic link to the ASRR shear zone remain poorly understood. Directly dating the ore-forming age of ruby deposits is improbable work because the simple formula $\mathrm{Al}_{2} \mathrm{O}_{3}$ of ruby, none of radioactive elements (e.g. $\mathrm{U}, \mathrm{Th}, \mathrm{Pb}$ ) are detectable by using the present instruments. Therefore, indirect methods were widely used to constrain the age of ruby mineralization, such as ${ }^{40} \mathrm{Ar}-{ }^{39} \mathrm{Ar}$ dating of syngenetic micas, $\mathrm{U}-\mathrm{Pb}$ dating of zircon and rutile inclusions in the rubies. Here, we took a comprehensive approach to constrain the ore-forming ages of the Yuanjiang ruby deposit.

${ }^{40} \mathrm{Ar}-{ }^{39} \mathrm{Ar}$ dating the phlogopites yielded the ages of 22.2-22.5 $\mathrm{Ma}$ and ${ }^{238} \mathrm{U}_{-}{ }^{206} \mathrm{~Pb}$ dating the zircon and rutile inclusions in the rubies obtained the age of $36.2 \pm 1.1 \mathrm{Ma}(\mathrm{MSWD}=1.4,2 \sigma, \mathrm{n}=$ 4) and $20.9 \pm 1.0 \mathrm{Ma}(\mathrm{MSWD}=1.2, \mathrm{n}=22)$ after ${ }^{207} \mathrm{~Pb}$-based correction, respectively. The ${ }^{40} \mathrm{Ar}-{ }^{39} \mathrm{Ar}$ ages of phlogopite and the ${ }^{238} \mathrm{U}_{-}{ }^{206} \mathrm{~Pb}$ age of rutile inclusions were interpreted as the lower limits of ruby crystallization because the relatively lower closure temperature of isotopic system than the ore-forming temperature of marble-hosted ruby deposit. Conversely, the ${ }^{238} \mathrm{U}^{2}{ }^{206} \mathrm{~Pb}$ age of zircon inclusions represents the timing of the ruby mineralization owing to the approaching temperature between the ruby crystallization and isotopic system closure.

Therefore, associated with the tectonic evolution of the Ailaoshan- Red River shear zone, we propose that the oreforming of the Yuanjiang marble-hosted ruby deposit were triggered by the regional subduction-collision and then transporting to the subsurface by the left lateral shearing. 